\title{
Involvement of Mutagens in the Production of Bioethanol by Saccharomyces cerevisiae: A Review
}

\section{Ghulam Rabbani}

Department of Chemistry, Lalit Narayan Mithila University, Darbhanga, Bihar, India

“Corresponding author: Ghulam Rabbani, Department of Chemistry, Lalit Narayan Mithila University, Darbhanga, Bihar, India, Tel: +919931870344; E-mail: rabbanidbg@gmail.com

Received date: September 13, 2018; Accepted date: October 09, 2018; Published date: October 12, 2018

Copyright: (C) 2018 Rabbani G. This is an open-access article distributed under the terms of the Creative Commons Attribution License, which permits unrestricted use, distribution, and reproduction in any medium, provided the original author and source are credited.

\begin{abstract}
A mutagen is a physical or chemical agent that changes the genetic material, usually DNA, of an organism and thus increases the frequency of mutations above the natural background level. nowadays many chemical mutagens like 1, 2-dimethyl hydrazine, Quercetin, Bromo acetaldehyde, Ketoconazole etc. in the production of bioalcohol. It was observed that in presence of mutagens the production of bio alcohol by Saccharomyces cerevisiae Rb-39 increased by $2.5 \%$ to $17.5 \%$.
\end{abstract}

Keywords: Mutagens; Fermentation; 1, 2-dimethyl hydrazine; Quercetin; Bromo acetaldehyde; Ketoconazole

\section{Review}

The term mutation refers both to the change in the genetic material and to the process by which the change occurs. Mutation is the ultimate source of all genetic variation; it provides the raw material for evolution.

A number of chemicals were found to be mutagenic in both plants and animals [1-3]. Friedrich and Zimmermann [4], for example, found that nitrous acid was effective in causing mutations in Aspergillus. In Drosophila that mutation could be induced by nitrogen and Sulphur mustards [5].

Lawley [6] and others discovered mutagenic activity in formaldehyde, diethylsulphate, diazomethane, and other compounds. Most of these chemicals also caused severe skin irritations in mammals and many were cancer-producing as well. In fact, many chemicals were first tested for mutagenic activity simple on the basis of prior skin or cancer tests. Since then hundreds of chemical agents have been found to produce mutagenic activity in a variety of organisms and important new methods have been devised for discovering such activity.

In general, however, prediction of mutagenic activity cannot be made on the basis of chemical structure alone. Some compounds, for example, affect certain organisms but not others, while some are restricted in action to specific developmental stages or to a specific (e.g., formaldehyde).

The search for genes that respond differently to mutagenic agents had some success, but no mutagen was found that confined its effects to only one particular gene on a chromosome and affected no others at all [7]. Thus, the wide array of compound that because mutations made it difficult for a long period to assign any specific reaction in the cell to a particular mutagen.

A crioline dyes such as proflavine and acridine orange are other mutagens that seem to produce direct effects on the DNA molecule. According to Loeber [8], acridine dyes act by inserting themselves between two neighboring purine bases in single DNA strand. The consequence of such incorporation, according to Stumpf and Copeland [9], is to cause either the insertion or deletion of a single nucleotide. Thus, acridine mutations would not be expected to cause transitions as do base analogues, nitrous acid, hydroxylamine, and alkylating agents [10].

Miller [11] performed a classic experiment or $r$ II mutations in phase $\mathrm{T}_{4}$. His procedure was to induce and collect R-99 mutations caused by all these agents and then test whether reverse mutation to normal $\left(\mathrm{r}^{+}\right)$could be induced by the 2-aminopurine and 5bromouracil that they themselves produced. Similarly, they could revert high percentages of $\mathrm{r}-99$ mutation that had been caused by hydroxylamine, nitrous acid, and alkylating agents. The most revealing findings about mutation have come from the studies of some mutagenic chemicals as well radiation energy $[11,12]$. General reviews reveal that there is a rather widespread agreement as to the best strategy for a program of strain development of screening designed to improve best and potent mutant of micro-organism [13-16]. Singh [17] in his investigation on microbial biosynthesis of lactic acid by Lactobacillus acidophilus acid found that only hydrazine sulphate enhances the microbial biosynthesis of lactic acid while pnitrophenylhydrazine-2,4-dinitrophenythydrazine and lithium fluoride has been found almost detrimental valueless for the microbial synthesis of lactic acid.

Billoval [18] also worked on a few chemical mutagens and found that only methoxy caffeine enhances the fungal synthesis of ergotalkaloids while sodium azide, hydrazine hydrochloride, and lithium fluoride has been found almost detrimental and valueless for the fungal synthesis of ergot-alkaloids by Arnold [19].

A large variety of compounds like peroxides, caffeine, gaseous butadiene, Ethelene and thiourea chemicals were also reported by a group of workers as very specific mutagens [20-24]. Nishi et al. [25] have worked on microorganisms and fermentation process such as $\mathrm{N}$ methyl-N-nitroso urea, EMS, or X-rays to induce the microbial process and achieved the improved yields. Dubey and Tiwari [26,27] have also reported the mutagenic properties of ethyl methyl sulphonate (EMS). Tiwari et al. $[27,28]$ found that lactic acid fermentation process was inhibited with increasing concentration of camphor. 
Several phenolics flavonids and aldehydes were also found mutagenic in variety of strain of different fungi and bacteria [29-32]. Some urethanes also behave as a typical mutagen. Its mutagenic properties have been established by Stankowski et al. [33].

Indophenols also has inhibitory effect on anaerobic fermentation using yeast suspension. Rizwan [34] found appreciable mutagenic action of hydrazine at $1.0 \mathrm{M}$ optimum concentration. The alkylated hydrazine has also been found to be specific mutagen but was not as effective as hydrazine. Hydroxylamine [35] has been found to be most specific mutagenic chemical for a number of microbes.

Singh and Harigae [36] in their investigations reported chloralhydrate as a growth inhibitor chemical mutagen. Ang et al. [37] also reported chloralhydrate as a strong mutagenic chemical for styphimurian but it has been found weak mutagenic. in many other cases. Sorensen et al. [38] reported Chloralhydrate as a retards production of lactic acid by delbrueckii [38]. Colchi-mutation has also been reported by $\mathrm{Xu}$ et al. [39,40].

Proflavin and acridine orange are two important mutagenic dyes [41]. The mechanism of dyes action is not fully understood, and it may take place during recombination. The influence on various dyes on activity of different microbes have been reported by a group of workers [42-46].

Yim et al. [47] demonstrated the influence of the ionizing radiations to induce mitosis gene conversion by using diploid strain of $S$. cerevisiae. Gamma rays and ultrasonic waves were found as effective mutagens for lactic culture and the fungus $A$. niger [47-51].

Guo and $\mathrm{Li}$ [51] has also studied some chemical mutagens or fermentation processes and has reported only benzyl carbamate has significant influence while 2, 4- dinitrophenyl hydrazine, acetone phenyl hydrazone and Acetaldehyde phenylhydrazone insignificant for fermentative process, especially for citric acid fermentation.
Chin et al. [52] studied efficacy of P-toluene sulphonyl azide and ptoluene sulphonyl hydrazine on microbial synthesis of bio alcohol and found that $\mathrm{p}$-toluene sulphonyl azide retards that yield of bio alcohol while p-toluene sulphonyl hydrazine enhances the yield significantly.

Dan et al. [53] reported salicyloyl hydrazine and benzoyl hydrazine as a specific mutagen for fermentative production of tactic acid by Lactobacillus bulgaricus-2056. Li et al. [54] again reported 2aminofluorene and dimethyl nitrosamines as a Chemicals mutagen for lactic acid fermentation. Chan and Liu [55] observed ethylene oxide and butyl carbamate as an effective chemical mutagen for alcoholic fermentation.

Novy et al. [56] has reported Et Br very useful chemical mutagen for homolactic acid fermentation. They further found Nitrofurazone as a strong chemical mutagen for homolactic acid fermentation [57].

Thus, it is obvious that most of the chemical mutagens are very useful for different fermentation process.

It is obvious from the above review of literature that various chemical mutagens and some other mutagenic agents are used to produce mutants. If microbial population exposed to the effect of mutagens differs in cultural properties, then these mutations may be differentiated according to size, shape, structure, and color of the colonies. Mutations of biochemical properties are revealed by means of minimal media containing only salts and carbohydrates (Table 1).

Comparative study of the influence of 1, 2-demethyl hydrazine, Quercetin, bromo acetaldehyde and ketoconazole on alcoholic fermentation by Saccharomyces cerevisiae Rb-39 in $50 \mathrm{hrs}$ Ghulam [58].

\begin{tabular}{|c|c|c|c|c|c|c|}
\hline S. No & $\begin{array}{l}\text { Chemical mutagens } \\
\text { used }\end{array}$ & $\begin{array}{l}\text { Optimum } \\
\text { concentration } \\
\text { mutagens used }\end{array}$ & $\begin{array}{l}\text { Maximum yield } \\
\text { of Bioalcohol in } \\
\text { control } \mathrm{ml} / 100 \\
\mathrm{ml}\end{array}$ & $\begin{array}{lrr}\text { Maximum } & \text { yield of } \\
\text { bioalcohol in presence of } \\
\text { Different } \\
\mathrm{ml} / 100 \mathrm{ml}\end{array}$ & $\begin{array}{l}\% \text { Difference in the yield of } \\
\text { bioalcohol inorase }(+) \text { in } 50 \\
\text { hours of incubation period }\end{array}$ & Reference \\
\hline 1 & $\begin{array}{l}\text { 1,2-dimethyl } \\
\text { hydrazine }\end{array}$ & $6.0 \times 10^{-5} \mathrm{M}$ & 6.98 & 7.15 & $(+) 2.43553$ & [57] \\
\hline 2 & Quercetin & $6.0 \times 10^{-5} \mathrm{M}$ & 6.93 & 7.5 & $(+) 8.22510$ & [57] \\
\hline 3 & Bromo acetaldehyde & $3.0 \times 10^{-5} \mathrm{M}$ & 6.95 & 7.28 & $(+) 4.74820$ & [57] \\
\hline 4 & Ketoconazole & $6.0 \times 10^{-5} \mathrm{M}$ & 7.03 & 8.28 & $(+) 17.78093$ & [57] \\
\hline
\end{tabular}

Table 1: Each value represents mean of three trials, where $(+)$ values indicate $\%$ increase in the yield of bio alcohol.

\section{Conclusion}

Thus, it is concluded that a large number of mutagens have been employed to generate the mutants of different microbes but still there are chemical inorganic mutagens whose influence on alcoholic fermentation by species of yeast have not been well studied and established. Moreover, a survey of the literature reveals that there has been not enough mention to study the alcoholic fermentation exposed to mutagens especially chemical mutagens.

\section{References}

1. Rudolfs W, Babbitt H, Bloodgood D, Edwards G, Eldridge E, et al. (1949) A Critical Review of the Literature of 1948 on Sewage and Waste Treatment and Stream Pollution. Sewage Works Journal 21: 228-267.

2. Krone CA, Sophia MJY, Iwaoka WT (1986) Mutagen Formation during Commercial Processing of Foods. Environmental Health Perspectives 67: 75-88.

3. Abelson PH (1983) Dietary Carcinogens. Science 221: 1249-1249.

4. Zimmermann FK (1977) Genetic effects of nitrous acid. Mutation Research/Reviews in Genetic Toxicology 39: 127-148.

5. Sobels FH (1973) Some aspects of chemical mutagenesis. Agents and Actions 3: 68-72. 
6. Lawley PD (1966) Effects of Some Chemical Mutagens and Carcinogens on Nucleic Acids. Progress in Nucleic Acid Research and Molecular Biology 5: 89-131.

7. Shukla Y, Kalra N (2007) Cancer chemoprevention with garlic and its constituents. Cancer Letters 247: 167-181.

8. Loeber G, Achtert G (1969) On the complex formation of acridine dyes with DNA. 7. Dependence of the binding on the dye structure. Biopolymers 8: 595-608.

9. Stumpf JD, Copeland WC (2014) MMS exposure promotes increased MtDNA mutagenesis in the presence of replication-defective diseaseassociated DNA polymerase variants. PLoS Genet 10: 1-13.

10. Martinez C, de Geus P, Stanssens P, Lauwereys M, Cambillau C (1993) Engineering cysteine mutants to obtain crystallographic phases with a cutinase from Fusarium solani pisi, Protein Engineering. Design and Selection 6: 157-165.

11. Miller EC, Miller JA (1971) The Mutagenicity of Chemical Carcinogens: Correlations, Problems, and Interpretations. In: Hollaender A (eds.) Chemical Mutagens, pp: 83-119.

12. Brookes P (1977) Mutagenicity of polycyclic aromatic hydrocarbons. Mutation Research/Reviews in Genetic Toxicology 39: 257-283

13. Ward JF (1995) Radiation Mutagenesis: The Initial DNA Lesions Responsible. Radiation Research 142: 362-368.

14. Stewart RD, Yu VK, Georgakilas AG, Koumenis C, Park JH, et al. (2011) Effects of Radiation Quality and Oxygen on Clustered DNA Lesions and Cell Death. Radiation Research 176: 587-602.

15. Holt SM, Georgakilas AG (2007) Detection of Complex DNA Damage in $\gamma$-Irradiated Acute Lymphoblastic Leukemia Pre-B NALM-6 Cells. Radiation Research 168: 527-534.

16. Miller JH (1996) Spontaneous Mutators in Bacteria: Insights into Pathways of Mutagenesis and Repair. J Annual Review of Microbiology, pp: 625-643.

17. Singh S, Chakravarty I, Kundu S (2017) Mathematical modelling of bioethanol production from algal starch hydrolysate by Saccharomyces cerevisiae. Cell Mol Biol 63: 83-87.

18. Bilovol Y, Panaccione DG (2016) Functional analysis of the gene controlling hydroxylation of festuclavine in the ergot alkaloid pathway of Neosartorya fumigata. Curr Genet 62: 853-860.

19. Arnold SL, Panaccione DG (2017) Biosynthesis of the Pharmaceutically important fungal ergot alkaloid dihydrolysergic acid requires a specialized allele of cloA. Appl Environ Microbiol 83: 1-10.

20. Bragg E, Maust MD, Daniel G (2017) Panaccione Ergot Alkaloid Biosynthesis in the Maize (Zea mays) Ergot Fungus Claviceps gigantea Paige. Journal of Agricultural and Food Chemistry 65: 10703-10710.

21. Ohta Y, Yashiro K, Kobayashi T (2017) Protective effect of N, N'dimethylthiourea against stress-induced gastric mucosal lesions in rats. Fundam Clin Pharmacol 31: 319-328.

22. Liu Y, Brito J, Dorris MR (2016) Isoprene photochemistry over the Amazon rain forest. Proc Natl Acad Sci 113: 6125-6130.

23. Inami K, Shiino J, Hagiwara S (2015) Transnitrosation of non-mutagenic $\mathrm{N}$-nitrosoproline forms mutagenic N-nitroso-N-methylurea. Bioorg Med Chem 23: 3297-3302.

24. Narendranath NV, Thomas KC, Ingledew WM (2000) Urea hydrogen peroxide reduces the numbers of lactobacilli, nourishes yeast, and leaves no residues in the ethanol fermentation. Appl Environ Microbiol 66: 4187-4192.

25. Nishi T, Ulziibat G, Khanui B (2015) Genome Sequence of Foot-andMouth Disease Virus of Serotype O Lineage Ind-2001d Isolated from Cattle in Mongolia in 2015. Genome Announcements 5: 1-2.

26. Mehtani J, Arora N, Patel A (2017) Augmented lipid accumulation in ethyl methyl sulphonate mutants of oleaginous microalga for biodiesel production. Bioresource Technol 242: 121-127.

27. Dubey P, Mishra AK, Singh AK (2015) Comparative analyses of genotoxicity, oxidative stress and antioxidative defense system under exposure of methylparathion and hexaconazole in barley. Environ Sci Pollut Res Int 22: 19848-1959.
28. Probst M, Walter A, Dreschke G (2015) End-product inhibition and acidification limit biowaste fermentation efficiency. Bioresour Technol 198: 540-549.

29. Devi A, Archana KM, Bhavya PK (2018) Non-anthocyanin polyphenolic transformation by native yeast and bacteria co-inoculation strategy during vinification. J Sci Food Agric 98: 1162-1170.

30. Ali A, Rahman K, Jahan N (2016) Protection of DNA during oxidative stress and cytotoxic potential of Artemisia absinthium. Pak J Pharm Sci 29: 295-299.

31. Cueva C, Moreno-Arribas MV, Martin-Alvarez PJ (2010) Antimicrobial activity of phenolic acids against commensal, probiotic and pathogenic bacteria. Res Microbiol 161: 372-382.

32. Kim H, Lee HS, Park H (2017) Enhanced production of xylitol from xylose by expression of Bacillus subtilis arabinose: $\mathrm{H}+$ symporterand Scheffersomyces stipitis xylose reductase in recombinant Saccharomyces cerevisiae. Enzyme Microb Technol 107: 7-14.

33. Stankowski LF, Aardema MJ, Lawlor TE (2015) Integration of Pig-a micronucleus, chromosome aberration and comet assay endpoints in a 28-day rodent toxicity study with urethane. Mutagenesis 30: 335-342.

34. Rizwan M, Aslam M, Asghar MJ (2017) Pre-breeding of lentil (Lens culinaris Medik.) for herbicide resistance through seed mutagenesis.

35. Wang J, Yang S, Zhang K (2016) A simple and sensitive method to analyze genotoxic impurity hydrazine in pharmaceutical materials. J Pharm Biomed Anal 126: 141-147.

36. Harigae R, Moriyama K, Togo H (2014) Preparation of 3,5-disubstituted pyrazoles and isoxazoles from terminal alkynes, aldehydes, hydrazines, and hydroxylamine. J Org Chem 79: 2049-2058.

37. Ang J, Song LY, D'Souza S (2016) Mutagen Synergy: Hypermutability Generated by Specific Pairs of Base Analogs. J Bacteriol 198: 2776-2783.

38. Sorensen KI, Curic-Bawden M, Junge MP (2016) Enhancing the Sweetness of Yoghurt through Metabolic Remodeling of Carbohydrate Metabolism in Streptococcus thermophilus and Lactobacillus delbrueckii subsp bulgaricus. Appl Environ Microbiol 82: 3683-3692.

39. Xu Q, Zang Y, Zhou J (2016) Highly efficient production of D-lactic acid from chicory-derived inulin by Lactobacillus bulgaricus. Bioprocess Biosyst Eng 39: 1749-1757.

40. Zhang C, Zhou C, Assavasirijinda N (2017) Non-sterilized fermentation of high optically pure D-lactic acid by a genetically modified thermophilic Bacillus coagulans strain. Microb Cell Fact 16: 213.

41. Li C, Zhang GF, Mao X (2016) Growth and acid production of Lactobacillus delbrueckii ssp. bulgaricus ATCC 11842 in the fermentation of algal carcass. J Dairy Sci 99: 4243-4250.

42. Nakamura T, Kusuzaki K, Matsubara T (2014) Determination of the LD50 of acridine orange via intravenous administration in mice in preparation for clinical application to cancer therapy. In Vivo 28: 523-527.

43. Mani P, Keshavarz T, Chandra TS (2017) Decolourisation of Acid orange 7 in a microbial fuel cell with a laccase-based biocathode: Influence of mitigating $\mathrm{pH}$ changes in the cathode chamber. Enzyme Microb Technol 96: $170-176$.

44. De Pinillos MBA, Mroz P, Thunshelle C (2017) Design features for optimization of tetrapyrrole macrocycles as antimicrobial and anticancer photosensitizers. Chem Biol Drug Des 89: 192-206.

45. Chudzik B, Czernel G, Miaskowski A (2017) Amphotericin B-copper(II) complex shows improved therapeutic index in vitro. Eur J Pharm Sci 97: 9-21.

46. Oon YL, Ong SA, Ho LN (2018) Up-flow constructed wetland-microbial fuel cell for azo dye, saline, nitrate remediation and bioelectricity generation: From waste to energy approach [epub ahead of print]. Bioresour Technol 266: 97-108.

47. Yim E, O'Connell KE, St Charles J (2014) High-resolution mapping of two types of spontaneous mitotic gene conversion events in Saccharomyces cerevisiae. Genetics 198: 181-192.

48. Abbaszadeh S, Tavakoli R, Sharifzadeh A (2015) Lactic acid bacteria as functional probiotic isolates for inhibiting the growth of Aspergillus 
Citation: Rabbani G (2018) Involvement of Mutagens in the Production of Bioethanol by Saccharomyces cerevisiae: A Review. J Environ Anal

Page 4 of 4

flavus, A. parasiticus, A. niger and Penicillium chrysogenum. J Mycol Med 25: 263-267.

49. Yin D, Xu G, Wang M (2017) Effective cell trapping using PDMS microspheres in an acoustofluidic chip. Colloids Surf B Biointerfaces 157: 347-354.

50. Moghaddam ZH, Mokhtari-Dizaji M, Movahedin M (2017) Estimation of the distribution of low-intensity ultrasound mechanical index as a parameter affecting the proliferation of spermatogonia stem cells in vitro. Ultrason Sonochem 37: 571-581.

51. Guo XW, Li YZ, Guo J (2016) Reduced production of ethyl carbamate for wine fermentation by deleting CAR1 in Saccharomyces cerevisiae. J Ind Microbiol Biotechnol 43: 671-679.

52. Chin YW, Kang WK, Jang HW (2016) CAR1 deletion by CRISPR/Cas9 reduces formation of ethyl carbamate from ethanol fermentation by Saccharomyces cerevisiae. J Ind Microbiol Biotechnol 43: 1517-1525.

53. Dan T, Wang D, Wu S (2017) Profiles of Volatile Flavor Compounds in Milk Fermented with Different Proportional Combinations of Lactobacillus delbrueckii subsp Bulgaricus and Streptococcus thermophilus.
54. Li J, Zhu C, Tu M (2015) Effect of carbonyl inhibitors and their HO detoxification on lactic acid fermentation. Appl Bio Chem Biotechnol 175: $3657-367$

55. Chen D, Liu SQ (2016) Transformation of chemical constituents of lychee wine by simultaneous alcoholic and malolactic fermentations. Food Chem 196: 988-995.

56. Novy V, Brunner B, Muller G (2017) Toward "homolactic" fermentation of glucose and xylose by engineered Saccharomyces cerevisiae harboring a kinetically efficient 1-lactate dehydrogenase within pdc1-pdc5 deletion background. Biotechnol Bioeng 114: 163-171.

57. Puri P, Goel A, Bochynska A (2014) Regulation of acetate kinase isozymes and its importance for mixed-acid fermentation in Lactococcus lactis. J Bacteriol 196: 1386-1393.

58. Rabbani G (2018) Submerged Fermentation (SMF) process in the studies on bio-alcohols. PhD Thesis, LNM University, Darbhanga, Bihar, India, pp: $75-111$. 